\title{
Morphological Phylogenetic Analysis of Two Early-Diverging Genera of Bromelioideae (Bromeliaceae)
}

\author{
Raquel Fernandes Monteiro ${ }^{1,2}$, André Mantovani ${ }^{1} \&$ Rafaela Campostrini Forzza $^{1}$
}

\begin{abstract}
Bromelia includes 66 species, grouped in three subgenera: Bromelia, Distiacanthus and Karatas. The genus is one of the earlier divergent groups within Bromelioideae, a subfamily with innumerable problems of generic delimitation. Considering that few phylogenetic studies have included more than one species of Bromelia, the objectives of this study were to carry out a phylogenetic analysis for the genus, seeking to evaluate its monophyly as well as its subgenera, and to better understand the interspecific evolutionary relationships within the genus and the intergeneric relationships within Bromelioideae. Also included in the analysis were the two species of Fernseea, a genus originally described from a species placed in Bromelia. The phylogenetic analysis was conducted with combined micro- and macromorphological data, including 39 taxa with 116 characters. As in other studies on Bromeliaceae, the clades have low statistical support and many questions regarding the relationships of the groups remain. The circumscription of Bromelia is still uncertain, due to the position of B. irwinii; Fernseea seems to emerge within this genus, as the marority-rule consensus suggests, and the infrageneric categories are debatable because they do not constitute monophyletic groups. However, Bromelia seems to be paraphyletic and, without $B$. irwinii, the genus can be considered monophyletic. Beginning with the premise that the most recent common ancestor of Bromelioideae appeared first in the southern Andes, Bromelia and Fernseea seems to have dispersed along three biogeographical routes. The present work is an important contribution to understand the evolution and biogeography of the Bromelioideae.
\end{abstract}

Key words: Bromelia, Fernseea, dry diagonal, Brazilian Shield, morphology.

\section{Introduction}

The family Bromeliaceae includes about 3,320 species and has been subdivided into eight subfamilies (The Plant List 2013; Givnish et al. 2007, 2011). The Bromelioideae is the subfamily that has diverged more recentely among Bromeliaceae lineages, and frequently emerges as monophyletic and sister to Puyoideae (Givnish et al. 2004, 2007, 2011; Evans et al. 2015). About $85 \%$ of the more than 860 species of Bromelioideae occur in Brazil, with the major center of diversity in the Atlantic Forest (Martinelli et al. 2008; Forzza et al. 2014). The importance of this subfamily in the evolutionary history of the bromeliads is represented by the combination of an epiphytic habit, formation of a tank, CAM metabolism, and an extensive recent diversification in the Neotropical region, mainly in forest formations along the east coast of Brazil (Benzing 2000; Crayn et al. 2004). Bromelioideae taxonomy is very complex. Most genera are artificial, circumscribed using particular groups of morphological features rather than synapomorphies, and genera limits are often been redefined, since they are based on symplesiomorphies (Schulte et al. 2009).

Several phylogenies (Schulte et al. 2005, 2009; Givnish et al. 2011) agree that one of the earlier divergent lineages in Bromelioideae comprises five terrestrial genera that lack a leaf tank: Fascicularia, Ochagavia and Greigia, which have C3 metabolism and occur in humid environments; Deinacanthon, which presents CAM metabolism and occurs in the Chaco (Schulte et al. 2005); and Bromelia. The later is the largest genus among this earlydiverging lineage and includes species with

\footnotetext{
${ }^{1}$ Instituto de Pesquisas Jardim Botânico do Rio de Janeiro, R. Pacheco Leão 915, 22460-030, Rio de Janeiro, RJ, Brazil

${ }^{2}$ Author for correspondence: raquelfmbio@yahoo.com.br
} 
CAM metabolism. Its members are concentrated at low to intermediate altitudes ( 0 to $1200 \mathrm{~m}$ elev.), and occur widely in South and Central America, reaching their greatest diversity in areas with open vegetation and alternate wet and dry seasons; but are also found in more humid environments (Benzing 2000; Crayn et al. 2004; Monteiro et al. 2011). Another member of this early-branching lineage in Bromelioideae is the genus Fernseea (Schulte \& Zizka 2008; Schulte et al. 2009; Jabaily \& Systma 2010).

Bromelia includes 66 species (The Plant List 2013; Forzza et al. 2014) robust with curved spines on the leaf margins; showy flowers often covered by trichomes; petals chartaceous and fleshy, helmet-shaped to reflexed, from pink to red or lilac to purple, and smooth; with yellow berries (Mez 1891; Smith \& Downs 1979). Mez (1891) proposed a division of the genus into three subgenera: Bromelia subg. Distiacanthus, Bromelia subg. Bromelia and Bromelia subg. Karatas. The first subgenus includes species with petiolate leaves. In the second, species have inflorescences that extend outside the foliar rosette, as well as an ovary with sparse, white indumentum. The third subgenus includes species with inflorescences inside the foliar rosette, and an ovary with tomentose chestnutbrown indumentum (Fig. 1). In spite of Mez' proposal, Smith and Downs (1979) did not accept infrageneric categories in Bromelia.

Fernseea has only two species, both of which occur in southeastern Brazil, in montane regions with scrub vegetation ("campos de altitude", Vasconcelos 2011). The type species of the genus, F. itatiaiae (Wawra) Baker (Fig. 1), was described in Bromelia and some years later it was combined in the new genus Fernseea (Baker 1889). Nearly a century later, its congener F. bocainense was described by Pereira and Moutinho (1983). Fernseea is characterized by narrow leaf blades; bracts with a dense imbricate peduncle; a simple racemose inflorescence; well-developed floral bracts; pedicellate flowers with free, symmetrical sepals; free petals without appendices; stamens free and included; and a long epigynous tube (Smith \& Downs 1979).

Fernseea and Bromelia have seldom been analyzed simultaneously in the same phylogenetic analysis (Schulte et al. 2009; Evans et al. 2015). Fernseea forms a clade with Fascicularia and Ochagavia in a polytomy with Bromelia (Horres et al. 2007), or occurs as a sister to the eu- bromelioids (Schulte \& Zizka 2008). Bromelia appears either in a polytomy with Fascicularia, Deinacanthon and Ochagavia (Schulte et al. 2005), as a sister to Greigia and to Ochagavia and Fascicularia (Givnish et al. 2011), or as a sister to eu-bromelioids (Evans et al. 2015) or all other Bromelioideae (Givnish et al. 2007; Schulte et al. 2009; Sass \& Specht 2010).

Even though some morphological characters have been shown to be homoplastic (HornungLeoni \& Sosa 2008; Almeida et al. 2009; Gomesda-Silva et al. 2012; Schulte et al. 2009; Donadío et al. 2014), many of them continue to be extremely important in the delimitation of taxonomic groups in Bromeliaceae (Hornung-Leoni \& Sosa 2008; Almeida et al. 2009; Gomes-da-Silva et al. 2012), in contrast to the lack of molecular divergence in traditional analyzed fragments of DNA (Clark \& Clegg 1990; Horres et al. 2000; Schulte et al. 2005; Faria et al. 2004; Versieux 2009). Although intensive efforts have been made to search for new and informative DNA fragments together with the use of microsatellites (Versieux et al. 2012) and amplified fragment length polymorphism (AFLP; Rex et al. 2007; Louzada 2012), detailed studies of morphology are also necessary in order to reveal traits of evolution that might not appear in molecular phylogenies, and important for identifying morphological synapomorphies (Assis 2009).

In view of this situation, and using a morphological phylogenetic analysis, our aims were: (1) to test the monophyly of Bromelia and Fernseea, as well as (2) of the subgenera Bromelia, Distiacanthus and Karatas; (3) to examine the relationships among the species of the two genera; and (4) to discuss the adaptive radiation and geographical diversification of the early-diverging bromelioids during the conquest of the Brazilian Shield.

\section{Materials and Methods}

Taxon Sampling

Twenty-five species of Bromelia (13 of the subgenus Bromelia, 10 of Karatas, and 2 of Distiachanthus), the two species of Fernseea, 11 species from other related genera of Bromelioideae, and one from Puya were analyzed, in a total of 39 terminals (Appendix $\mathrm{a}$ and $\mathrm{b}$ ). The species of Bromelia were selected on the basis of their occurrence, particularly taxa that are the best delimited taxonomically and also 

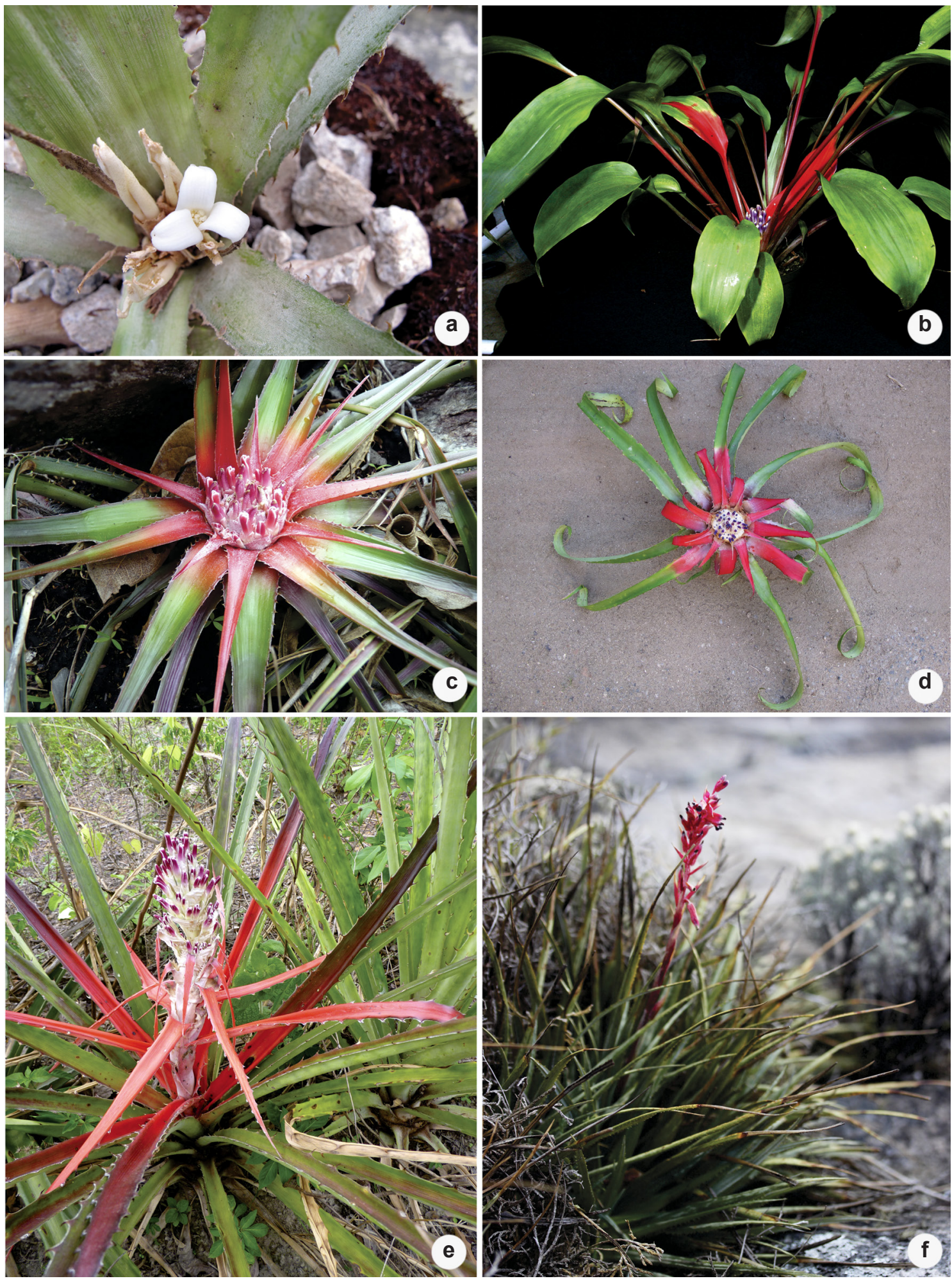

Figure 1 - a-b. Bromelia subg. Distiacanthus. - a. B. morreniana; b. B. scarlatina (Photo: B. Holst). c-d. Bromelia subg. Karatas. - c. B. macedoi; d. B. villosa. e. Bromelia subg. Bromelia. - B. balansae. f. Fernseea. - F. itatiaiae (Photo: M. Wolowski Torres). 
are well represented in the herbarium collections consulted. The voucher material is listed in Appendix a. We included all the patterns of morphological variation observed in the genera.

\section{Morphological dataset}

A data matrix of Species x Characters with 116 discrete characters, including 67 binary and 49 multistate characters (Apendix b), was constructed with the aid of the program Mesquite 2.7 (Maddison \& Maddison 2011). The characters list was built following Sereno [2007, (Table 1)]. All the characters were treated as unordered and were equally weighted. All the characters and their states are listed in table 1 . The macromorphological characters were analyzed for specimens obtained from field sampling, living collections, or herbarium specimens (Appendices a and $b$ ). The majority of the flowers analyzed were fixed in $70 \%$ ethanol at the time of collection. Existing published informations on the taxa, such as the color and position of the petals, were also used.

To obtain the micromorphological characters, the leaf anatomy of Bromelia was examined from freehand sections observed with a light microscope. The samples used were fixed in $70 \%$ ethanol; herbarized leaves were used if fresh leaves were not available. The methodology followed Monteiro et al. (2011). Anatomical and macromorphological informations for some nonBromelia species were obtained from published descriptions (Sajo et al. 1998; Zizka et al. 1999; Forzza 2001; Mantovani \& Iglesias 2005; Leme \& Siqueira Filho 2006; Mantuano 2008; Mantovani et al. 2012). The terminologies adopted follow the definitions of Radford et al. (1974) and Weberling (1989) for macromorphology, and Tomlinson (1969) for micromorphology.

\section{Phylogenetic analysis}

The cladistics analyses used the criterion of maximum parsimony. We conducted a heuristic search with 1000 repetitions, using 10 trees per replication, by the branch-swapping algorithm of the tree bisection-reconnection (TBR) method, based on the character optimization method ACCTRAN (accelerated transformation optimization; Swofford \& Maddison 1992), unordered and unweighted, with retention of multiple most parsimonious trees (MAXTREE), using the program PAUP* $4 \mathrm{~b} 10$ for Macintosh
(Swofford 2002). Puya nana was used to root the tree, as this genus is sister to the Bromelioideae (Givinish et al. 2007; Nixon \& Carpenter 1993). Each branch support value was evaluated by bootstrap (BS), performed with random addition sequence of taxa, using TBR for two hundred replicates and holding 10 trees by step (Felsenstein 1985). The Bremer (B) support was also calculated increasing the number of the optimal tree steps until the branches have collapsed (Bremer 1994). The program Mesquite 2.7 was used to visualize the cladograms and to reconstruct the ancestral characters states (Maddison \& Maddison 2011) and the WinClada 1.00 .08 (Nixon 2002) to trace the characters on the trees.

\section{Biogeographical evaluation}

The biogeographical evaluation of the species of Bromelia and Fernseea used in the analysis was based on published data (Smith \& Downs 1979; Ramírez-Morillo et al. 2004; Forzza et al. 2014), original descriptions, field observations, and herbarium data. The maps were made with ESRI ${ }^{\circledR} \operatorname{ArcMap}^{\mathrm{TM}} 9.3$ program.

\section{Results}

The maximum-parsimony analysis generated 34 equally parsimonious trees with 951 steps, a consistency index (CI) of 0.379 , a retention index (RI) of 0.450 , and a rescaled consistency index (RC) of 0.170 . The strict consensus tree and the majority-rule tree are presented (Figs. 2, 3, 4).

Bromelia is paraphyletic, due to the positioning of $B$. irwinii (Fig. 4). Without this taxon the remaining species of the genus formed a group (Fig. 2, clade B) sustained by nine synapomorphies: rosette position in relation to the central axis during flowering ca. $45^{\circ}$, bracts of peduncle patent during anthesis, floral bracts equaling or exceeding ovary, but not sepals; petal carnose and oblong, fruit yellow, stomata apparatus below the level of the epidermis, vascular bundles of smaller diameter taller than wider and habit terrestrial.

Fernseea did not appear to be monophyletic (Figs. 3a, 4). However, this genus was recovered in the analyses as closely related to Bromelia, principally to $B$. irwinii. Although they appeared in a polytomy in the strict consensus (Fig. 2), the positioning of the two species of Fernseea $+B$. 


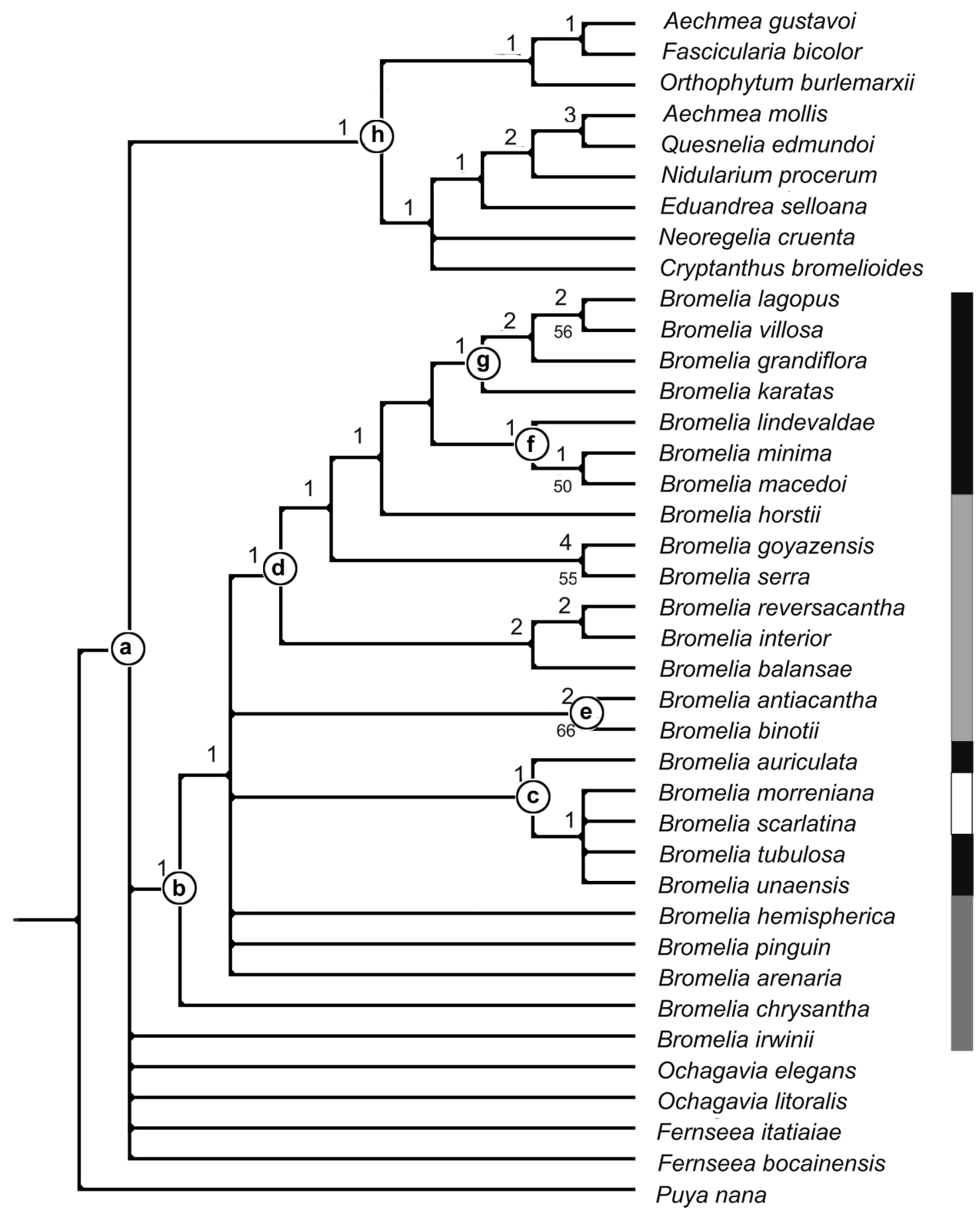

Figure 2 - Strict consensus of 34 most-parsimonious trees based on the analysis of 116 characters. The numbers below the branches correspond to the values of BS $(\geq 50)$, and numbers above the branches are the values of B. Black stripes represent the subgenus Karatas, gray stripes represent the subgenus Bromelia, and the white strip represents the subgenus Distiacanthus. 


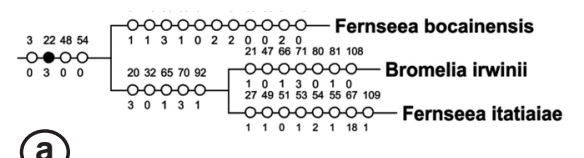

(a)

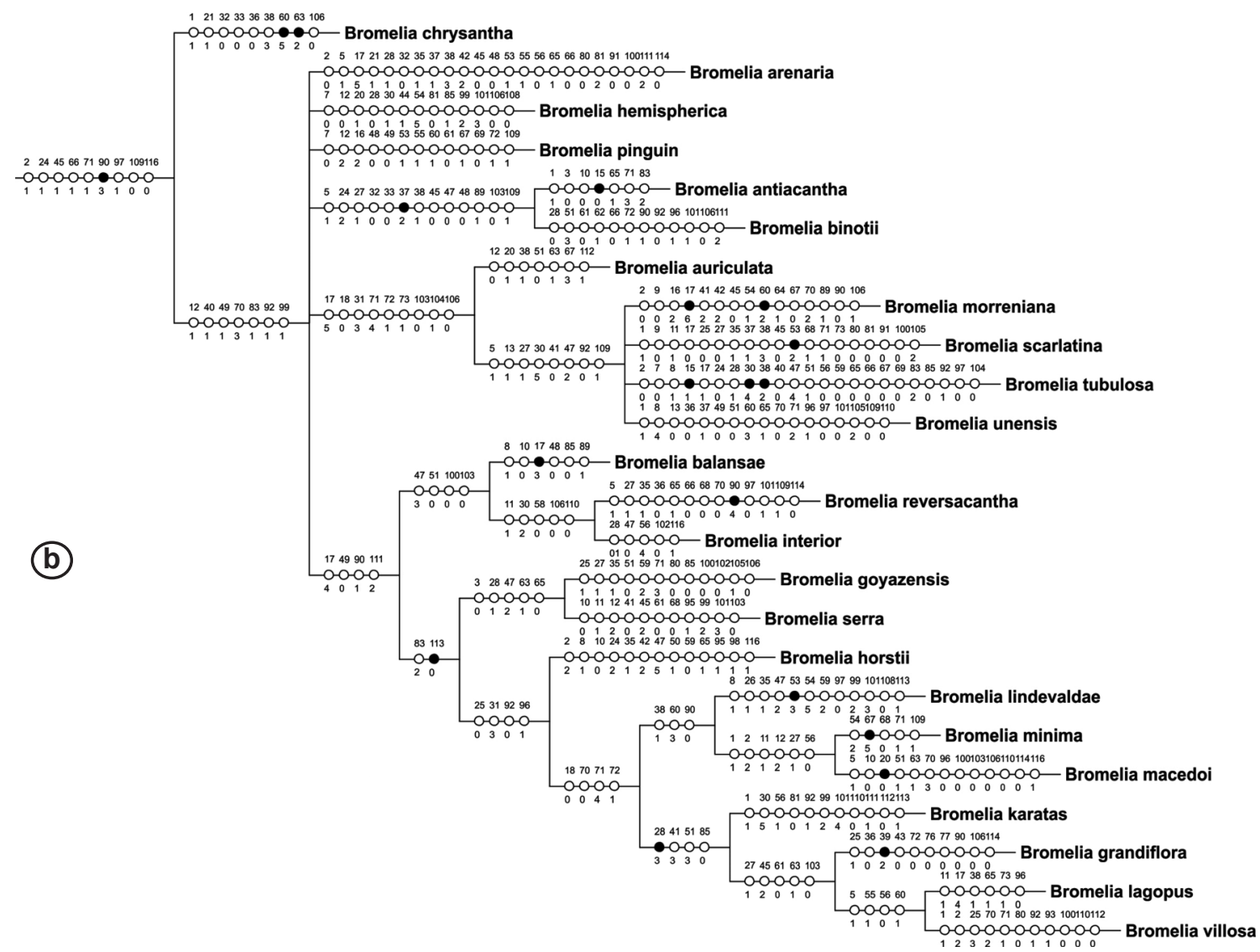

Figure 3 - a. Part of majority rule consensus of 34 most-parsimonious trees based on the analysis of 116 characters highlighting Fernseea and Bromelia irwinii; b. Part of strict consensus of 34 most-parsimonious trees based on the analysis of 116 characters highlighting Bromelia without Bromelia irwinii. Black circles represent non-homoplastic synapomosphies and white circles represent homoplastic synapomorphies. Numbers above branches correspond to characters while below branches correspond to character state according to table 1 .

irwinii at the base of Bromelia was recovered in $82 \%$ of the trees. The clade Bromelia+Fernseea is supported by four synapomorphies: leaf apex erect, peduncule pink, floral bract entire and sepal ovate (Fig. 3a).

Few of the clades were well supported by the bootstrap analysis. Bromelia antiacantha + B. binotii (Fig. 2, clade E) obtained 66\% BS and 2 for B, with the synapomorphies of: leaf apex pungent, primary bracts reflex during anthesis, bracts of peduncle apex pungent, flowers lax, branches of inflorescence high developed, primary bracts completely reflexed and oblong; floral bracts shorter than the ovary, ovate and entire; petals persistent during frutification, waterstorage hypodermis adaxial up to $1 / 3$ of the blade thickness and vascular bundles of smaller diameter thickening wider than tall; Bromelia goyazensis + B. serra obtained $55 \%$ for bootstrap and 4 for Bremer support, with the synapomorphies: leaf apex erect, bracts of peduncle tomentose, floral bracts, sepals aculeate and petal apex cuculate during the anthesis. Bromelia minima + B. macedoi obtained $50 \%$ support, with the 

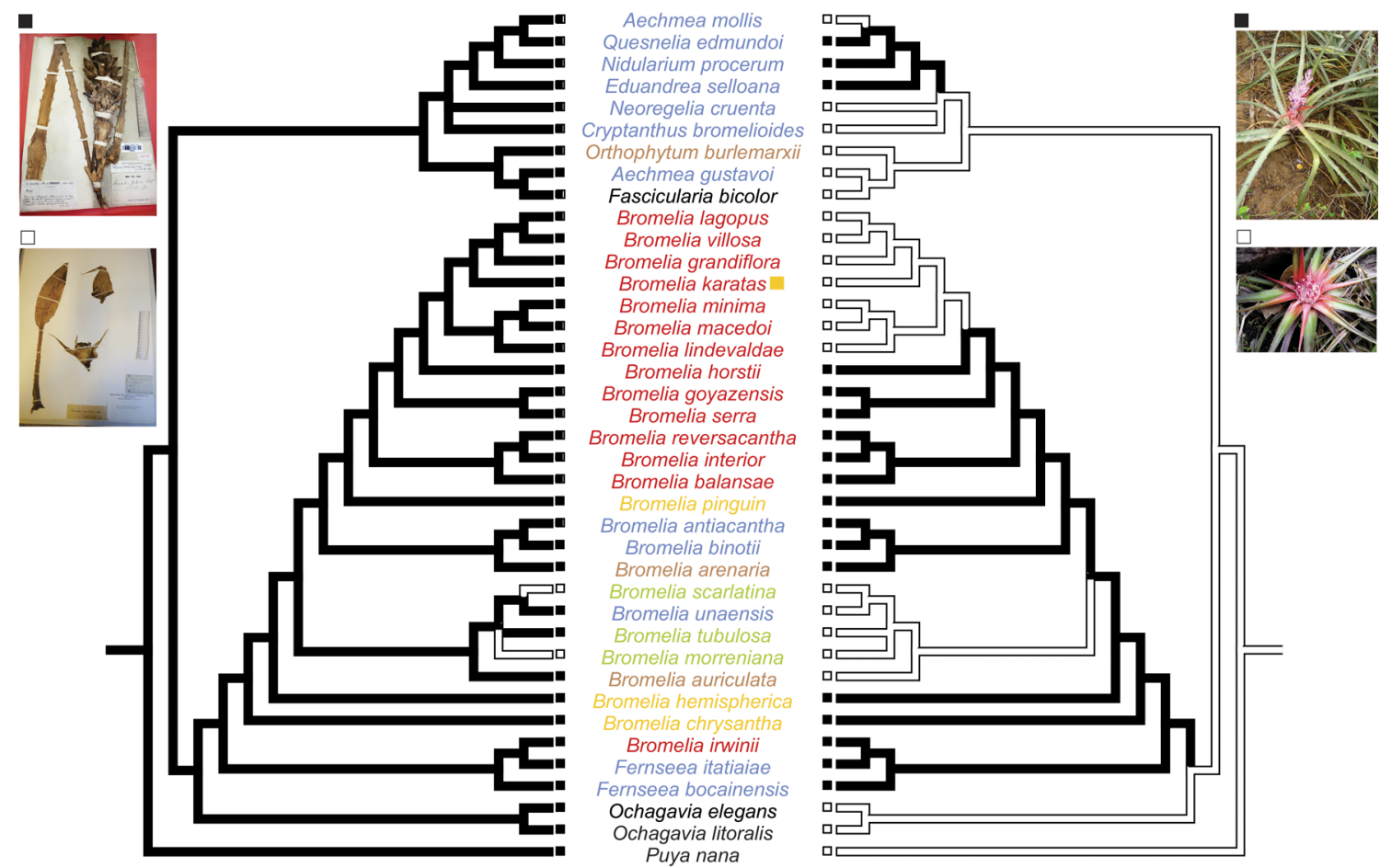

Figure 4 - Majority rule consensus of 34 most-parsimonious trees based on the analysis of 116 characters. Tree on the right: black branches indicate the presence of a peduncle (Bromelia arenaria); white branches indicate the absence of a peduncle (B. macedo $)$. Tree on the left: black branches indicate the absence of a petiole (B. balansae; Balansa 608, P); white branches indicate the presence of a petiole (B. scarlatina; Morren s.n., LG). Distribution of species: blue - Atlantic Forest, green - Amazon Forest, red - Cerrado, brown - Caatinga, yellow - Central America, black - Andes. The yellow square represents the presence of Bromelia karatas also in Central America.

synapomorphies: rosette position in relation to the central axis when sterile ca. $45^{\circ}$, rosette position in relation to the central axis during flowering ca. $90^{\circ}$, leaf-blade color when sterile green to red, leaf-blade color of central leaves of rosette during blooming completely red, bracts of peduncle with apex pungent and sepal white. Finally, the clade B. lagopus + B. villosa had $56 \%$ BS and 2 B support, supported by the leaves without apex pungent, sepals asymmetrical, white, and sepal apex attenuate. The remaining clades of the genus obtained less than $50 \%$ BS (Fig. 2).

Our results suggest that Bromelia subg. Karatas and Bromelia subg. Bromelia are paraphyletic. Nothing can be concluded about the monophyly of Bromelia subg. Distiacanthus, which emerged in a polytomy in the strict consensus (Figs. 2, 3b). Eight synapomorphies supported this group: leaves without apex pungent, leaf-blade chartaceous, bracts of peduncle with apex pungent, bracts of peduncle red, primary bracts lepidote, floral bract oblong, contour of leaf abaxial surface smooth to slightly wavy and vascular bundles of smaller diameter wider than tall.

Bromelia binotii and B. antiacantha (Fig. 2, clade E), species with large and lax inflorescence, appeared together in one clade supported by 13 synapomorphies (Figs. 2, 3b). Bromelia pinguin emerged just above in the majority-rule consensus, (Fig. 4), also has a large inflorescence. Clade D (Fig. 2) grouped species that occur predominantly in the Brazilian Cerrado and is possible to note the gradually reduction of the inflorescence upward the cladogram. B. balansae (Fig. 1), B. interior and $B$. reversacantha have a large but congested inflorescence; B. serra and B. goyazensis have little reduced and congested, but not sunk, inflorescence; and lastly the species of the F and G clades have 
a sunk and deeply congested inflorescence. The clade F (B. minima, B. macedoi and B. lindevaldae) consisted of small-sized species, while the clade $\mathrm{G}$ contained larger species (B. lagopus, B. villosa, $B$. grandiflora, and B. karatas).

In the majority-rule consensus (Fig. 4), Ochagavia emerged as a sister to Bromelia + Fernseea, and the remaining species of Bromelioideae were grouped in a single clade. However, in the strict consensus (Fig. 2), the clade Aechmea gustavoi, Orthophytum, Fascicularia and Cryptanthus + Neoregelia + A. mollis + Quesnelia + Nidularuim + Canistropsis (clade H) emerged in a polytomy with Bromelia, Fernseea and Ochagavia.

\section{Discussion}

All the phylogenies that have included more than one species of Bromelia have indicated that the genus is monophyletic (e.g., Schulte \& Zizka 2008; Sass \& Spech 2010; Silvestro et al. 2014; Evans et al. 2015). However, the monophyly of Bromelia was not confirmed in the present analysis, because of the positioning of $B$. irwinii.

Another novel result revealed in the majority consensus tree was Ochagavia, an Andean genus, as a sister-group of Bromelia + Fernseea. However, the strict consensus recovered a large polytomy between Bromelia, Fernseea, Ochagavia and the clade with the remaining species of Bromelioideae. The difficulty of establishing the relationships of Bromelia and Fernseea with the remaining members of Bromelioideae is also apparent from the different phylogenies based on molecular characters (e.g., Horres et al. 2007; Givnish et al. 2007, 2011; Schulte \& Zizka 2008; Schulte et al. 2009; Evans et al. 2015), where these genera emerge in different positions. These results illustrate the need for new studies to develop more conclusive and robust hypotheses, since the branches have low support (Schulte et al. 2009) and the schemes for the relationships among the early-diverging groups of Bromelioideae will likely be subject to frequent modification. Similarly, the relationship among Bromelia, Fernseea and Ochagavia remains unresolved, and further studies are needed in order to reach firm conclusions. The inclusion of other, non-Eubromelioideae taxa such as Greigia, Disteganthus, and especially Deinacanthon urbanianum (Mez) Mez, which has been included in Bromelia in the past (Smith 1967), and is often found in a sister-group position to this genus in molecular studies (Schulte et al. 2009; Givnish et al. 2011), requires further evaluation.

Bromelia irwinii appears together with Fernseea itatiaiae and F. bocainensis. Although Fernseea did not emerge as a sister of Bromelia in other phylogenetic studies, those that included species of Bromelia used only one to three species of this genus. The present study, since it included a good part of the species of Bromelia and both species of Fernseea, allowed us to reach firmer conclusions with respect to the phylogenetic affinity and the naturalness of these genera, even the strict consensus do not shows a good resolution.

The close relationship among Fernseea, Bromelia and Ochgavia that is apparent from the present results, constitutes an argument against the hypothesis that there was a single migration of the ancestral members of Bromelioideae from the Andes directly to high-altitude regions in southeastern Brazil, the region that is today the great center of diversity of the Bromelioideae (Schulte et al. 2005, 2009).

Although our results show weak support, making firm biogeographical conclusions premature, they do provide some insights into the evolution of Bromelioideae. The most recent common ancestor of the subfamily would have established itself first in the southern Andes (Zizka et al. 2009; Givnish et al. 2011), the locale where part of the present "basal-bromelioids" sensu Schulte et al. (2009) occur. Beginning with this premise, we can suggest, based on the phylogenetic analysis presented here, that there were three possible biogeographical routes for the clade Bromelia + Fernseea (Fig. 5):

\section{Route 1: Southern Andes $\rightarrow$ Northern Andes $\rightarrow$ Lowlands of the Amazon and Atlantic Forests Central America
Cowlands of the Amazon and Atlantic Forests}

This route could be represented by the ancestors of the Venezuelan and Colombian species, such as $B$. chrysantha; species of Central
America such as $B$. hemispherica; and clade $C$, which includes species of the Amazon Forest ( $B$. tubulosa, B. scarlatina and B. morreniana) and the 
Atlantic Forest of Brazil, with B. unaensis, which is restricted to forests in the lowlands of southern Bahia, and $B$. auriculata, which is restricted to fragments of the Atlantic Forest in Ceará.

The disjunction between the Amazon and Atlantic Forest lineages, principally in the region of the central corridor of the Atlantic Forest, is reported for a multitude of taxa (Amorim et al. 2008; Simonelli et al. 2008; Cavalcanti \& Tabarelli 2004). It is believed that the intense climate variations during the Pleistocene, in which expansions and retractions of forests occurred in glacial and interglacial periods, respectively (Haffer 1969; Prance 1987; Haffer $\&$ Prance 2002), reduced the extent of the dry areas between the Atlantic and Amazon Forests and allowed an exchange of species, including bromeliads (Givnish et al. 2011). For Bromelia this pattern appears in clade C (Fig. 2), and once again corroborates the recent differentiation of the species, as indicated for the entire family (Givnish et al. 2011).

Route 2: Southern Andes $\rightarrow$ High-altitude areas of the central Brazilian plateau (B. irwinii) $\rightarrow$ High-altitude fields of the Atlantic Forest domain (Fernseea)

This route was referred to as a long, direct route (high road), with dispersal from the Andes to the high-altitude fields of southeastern Brazil (Givnish et al. 2011). This type of distribution involves long-distance dispersal across the Brazilian Shield, and is associated with species that are endemic to high-altitude regions (Bromelia irwinii from the Chapada dos Veadeiros, rupicolous, 1,400 m elev.; Fernseea bocainensis from the Serra da Bocaina, rupicolous, 2,400 m elev.; and Fernseea itatiaiae from the Itatiaia Plateau, rupicolous, 2,400 $\mathrm{m}$ elev.)

\section{Route 3: Southern Andes $\rightarrow$ Chaco $\rightarrow$ Central Brazilian Plateau (Cerrado) $\rightarrow$ Caatinga \\ Lowlands of the Atlantic Forest}

This last route follows the dry diagonal (Prado \& Gibbs 1993), passing through the Chaco; arriving on the Central Brazilian Plateau, a locale of intense diversification of Bromelia; and later reaching the Caatinga, an area of intense hydric stress, and the lowlands of the Brazilian Atlantic coast. However, the species of clade E occurring in the Atlantic Forest domain, in contrast to the species that followed Route 1, are distributed in areas of restinga ( $B$. antiacanta and $B$. binotii). The restingas are sandy coastal flatlands of Pleistocene origin (ca. 10,000 years ago), where the species composition and physiognomic structure of the vegetation have a strong relationship to the Cerrado (Pereira \& Araujo 2000), and a similar microclimate, which is hotter, dry, and with more intense sunlight than in the adjacent humid forest environments (Mantovani $\&$ Iglesias 2005). The Caatinga and dry forests are environments with pronounced hydric seasonality (B. arenaria). This relationship to hydric seasonality is also observable in Bromelia pinguin, present in the same clade, which occurs in coastal and desert regions in Central America and Mexico.
The results obtained in this study suggest that the species of the Cerrado (except for B. irwinii) probably had a single origin, and that some taxa of this clade (e.g., B. serra and B. balansae) occupied other localities later. This hypothesis agrees with similar proposals for the Fabaceae (Novaes et al. 2010), of a single migration event followed by later diversification within the Cerrado biome. We can therefore conclude that the great evolutionary success of Bromelia began with the second occupation of the Cerrado (clade D); and that in the future, dated phylogenies may help to determine the time period when this radiation occurred. Therefore, it is possible to conclude that the Atlantic Forest domain was occupied by Bromelia through a series of repeated occupancy, as shown for Pitcairnia by Saraiva (2013), but differing from that found by Forzza (2001) for Encholirium.

Periods of aridification and increased frequency and intensity of fire might have had a more profound impact on species occurring in the already dry biomes (Simon et al. 2009), thus causing a higher rate of extinction among 
the tankless bromelioids (Silvestro et al. 2014). Nevertheless, these factors might have been strong forces driving the speciation and the evolutionary success of Bromelia in the Cerrado. Similarly, the repeated expansions and contractions of the Atlantic Rainforest and Cerrado during the Pleistocene (Pennington et al. 2004; Antonelli et al. 2009; Antonelli \& Sanmartin 2011; Silvestro et al. 2014) may have affected the occupation of Bromelia and its speciation in the Atlantic Rainforest (Bromelia antiacantha, B. unaensis and $B$. binotii). Probably it is also the key for the migration of members of Bromelioideae from arid environments to the evergreen forest, the present diversity center for this subfamily (Martinelli et al. 2008; Forzza et al. 2014).

Although the dry diagonal is the most problematic area for speciation and establishment of Bromelioideae, with a higher extinction rate of the terrestrial tankless lineages because of the harsher conditions (Silvestro et al. 2014), in this environment Bromelia underwent extensive diversity, making the Cerrado the most important biome in terms of species richness of this genus. The increased speciation rate could be associated with the water saving CAM physiology and the low competition for the niches, since they occupy sites in which plants with no adaptations for dry environments can not be established (Benzing 2000; Givnish et al. 2014; Silvestro et al. 2014).

The origin of taxa in open areas and subsequent occupation of forest areas, was previously discussed for Bromelioideae (Schulte et al. 2009), and can over again be suggested by our results. The most recent common ancestor of Bromelia, Fernseea and Ochagavia would have occupied open areas of the Andes and then migrated to other open areas, Cerrado, Chaco and high-altitude fields of the Atlantic Forest domain; and afterwards, to forest areas (Amazonia and Atlantic Forest). This same pattern was also found in Philodendron subgenus Meconostigma, which was originated in "campos rupestres" and Cerrado, followed latter by Amazonia and Atlantic Forest (Calazans et al. 2014).

Bromelia subg. Distiacanthus emerged unresolved (Fig. 2). The presence of a foliar petiole, uncommon in Bromeliaceae, is a homoplastic character, appearing in other genera such as Disteganthus, Cryptanthus and Pitcairnia (Smith \& Downs 1979; Saraiva 2013). This morphological condition, which is restricted to Bromeliaceae from shaded parts of forest environments, especially in species of the Amazon basin, makes it possible to reduce water loss via respiration through decreasing the area and thickness of the leaf, because of the limited photosynthetically active radiation that reaches the soil (Carswell et al. 2000). Little is known about the ontogenetic origin of the petiole in leaves of Bromeliaceae, but the sympatric existence of terrestrial bromeliads with petiolate $(B$. morreniana, B. scarlatina) and non-petiolate leaves (B. tubulosa), with or without a CAM metabolism (Pitcairnia), offers an opportunity to test hypothesis about carbon economy in future studies.

Bromelia tubulosa, B. unaensis and $B$. auriculata, according to Mez' (1891) definition of subgenera, belong in Karatas because of the leaf without a petiole and the inflorescence within the rosette. Nevertheless, this latter character

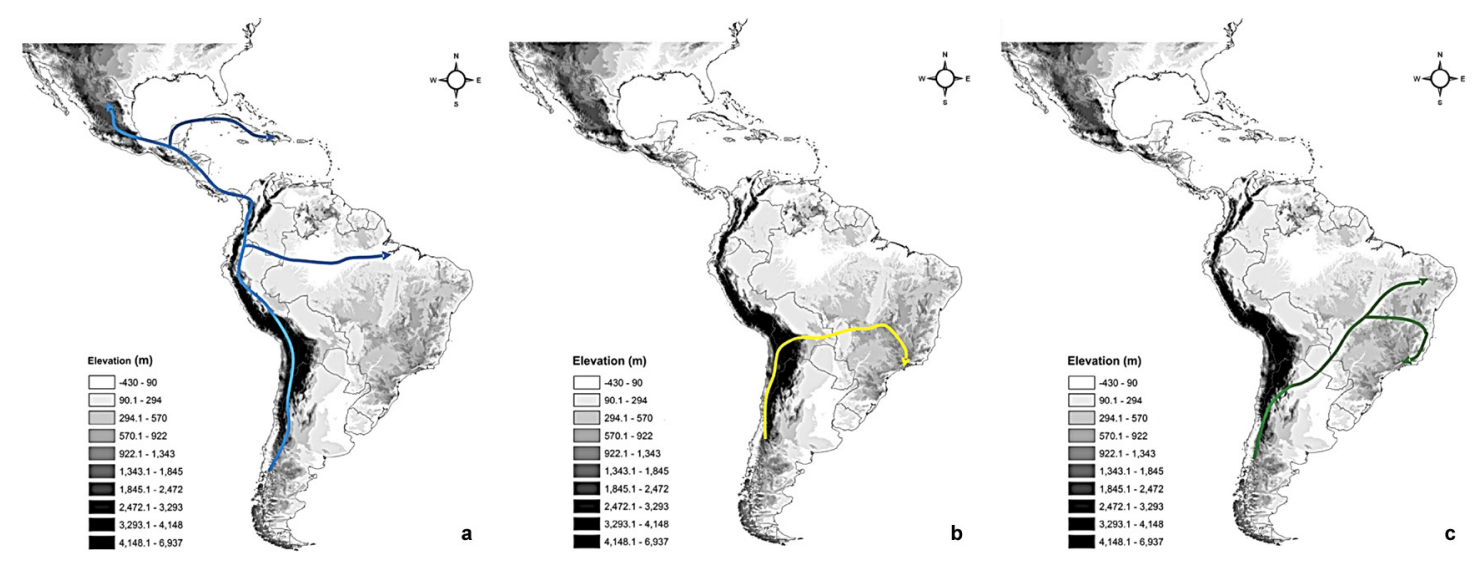

Figure 5 - Biogeographical routes proposed for Bromelia and Fernseea. a. Route 1; b. Route 2; c. Route 3. ESRI ${ }^{\circledR}$ $\operatorname{ArcMap}^{\mathrm{TM}}$ 9.3. 
Table 1 - Character and character status list.

1 Leaf, rosette position in relation to central axis when sterile: $0,15-30^{\circ} ; 1$, ca. $45^{\circ}$

2 Leaf, rosette position in relation to central axis during flowering: $0,15-30^{\circ} ; 1, \mathrm{ca} .45^{\circ} ; 2, \mathrm{ca} .90^{\circ}$

3 Leaf, apex, orientation: 0, Erect; 1, Reflex

4 Leaf, apex, form: 0, Attenuate; 1, Acute; 2, Obtuse; 3, Emarginate; 4, Apiculate

5 Leaf, apex, pungent: 0, Present; 1, Absent

6 Leaf, margin: 0, Entire; 1, Aculeate

Leaf, spines, orientation: 0, One orientation, antrorse; 1, One orientation, retrorse; 2, Two orientations, antrorse and retrorse, on same leaf.

8 Leaf, spines, color: 0, Brown; 1, Green; 2, Red; 3, Yellow; 4, Wine-colored

9 Leaf, petiole: 0, Present; 1, Absent

10 Leaf, differentiation between sheath and blade: 0, Abrupt; 1, Tenuous

11 Leaf, blade, color when sterile: 0, Completely green; 1, Green to red at apex; 2, Completely red;

Leaf, blade, color of central leaves of rosette during blooming: 0, Completely green; 1, Green to red at base;

2, Completely red

13 Leaf, blade, consistency: 0, Carnose; 1, Chartaceous

14 Leaf, sheath, indumentum: 0, Present; 1, Absent

15 Leaf, sheath, indumentum position: 0, Only on adaxial face; 1, Only on abaxial face; 2, On both faces

Leaf, sheath, type of indumentum on adaxial face: 0, Lepidote; 1, Tomentose; 2, Floccose; 3, Villous; 4, Pannose;

5, Sericeous

Leaf, sheath, type of indumentum on abaxial face: 0, Lepidote; 1, Tomentose; 2, Floccose; 3, Villous; 4, Pannose;

5, Sericeous; 6, Strigose

18 Inflorescence, peduncle, size related to the rosette: 0, Inside, peduncle very reduced; 1, Emergent

19 Inflorescence, peduncle, indumentum: 0, Present; 1, Absent

Inflorescence, peduncle, type of indumentum: 0, Velutinous; 1, Tomentose; 2, Floccose; 3, Villous; 4, Lepidote;

5, Sericeous

Inflorescence, peduncle, cover by bracts: 0 , Completely covered, imbricate bracts; 1 , Partially covered, lax bracts

Inflorescence, peduncle, color: 0, Completely white; 1 Red; 2, Green; 3, Pink; 4, Brown

Inflorescence, bracts of peduncle, size related to the internode: 0, Longer; 1, Shorter

Inflorescence, bracts of peduncle, position related to the peduncle during anthesis: 0, Erect; 1, Patent, $45^{\circ}-90^{\circ}$;

2, Completely reflexed

Inflorescence, bracts of peduncle, form: 0, Ovate; 1, Oblong; 2, Elliptical; 3, Lanceolate; 4, Linear

Inflorescence, bracts of peduncle, apex form: 0, Attenuate; 1, Acute; 2, Apiculate

Inflorescence, bracts of peduncle, apex pungent: 0 , Present; 1 , Absent

Inflorescence, bracts of peduncle, color: 0, Stramineous with red apex; 1, Green; 2, Pink; 3, Wine-colored; 4, White; 5, Red 
43 Inflorescence, primary bracts, margin: 0, Entire; 1, Aculeate

44 Inflorescence, primary bracts, color: 0, Red; 1, Green; 2, Pink; 3, Stramineous

Inflorescence, floral bracts, size: 0, Shorter than ovary 1 Equaling or exceeding ovary, but not sepals, 2, Equaling or exceeding sepals, but not petals, 3 , Equaling or exceeding petals

46 Inflorescence, floral bracts, color: 0, White; 1, Stramineous; 2, Red; 3, Pink; 4, Brown; 5, Blue; 6, Green

47 Inflorescence, floral bracts, form: 0, Ovate; 1, Oblanceolate; 2, Oblong; 3, Lanceolate; 4, Linear; 5, Triangular

48 Inflorescence, floral bracts, margin: 0, Entire; 1, Aculeate

49 Inflorescence, floral bracts, carin: 0, Present; 1 , Absent

50 Inflorescence, floral bracts, indumentum: 0, Present; 1, Absent

51 Inflorescence, floral bracts, type of indumentum: 0, Lepidote; 1, Tomentose; 2, Floccose, 3, Villous

52 Inflorescence, floral bracts, position of indumentum: 0, On apex only; 1, Covering floral bract

53 Inflorescence, floral bracts, apex: 0, Acute; 1, Attenuate; 2, Obtuse; 3, Rounded

54 Flower, sepal, form: 0, Ovate; 1, Obovate; 2, Oblong; 3, Lanceolate; 4, Linear; 5, Triangular; 6, Elliptical

55 Flower, sepal, symmetry: 0, Symmetrical; 1, Asymmetrical

56 Flower, sepal, color: 0, White; 1, Brown; 2, Blue; 3, Green; 4, Pink; 5, Stramineous

57 Flower, sepal, indumentum: 0, Present; 1, Absent

58 Flower, sepal, type of indumentum: 0, Lepidote; 1, Tomentose; 2, Floccose; 3, Villous

59 Flower, sepal, position of indumentum: 0, On apex only; 1, Covering sepal; 2, On base only

60 Flower, sepal, apex: 0, Acute; 1, Attenuate; 2, Obtuse; 3, Rounded; 4, Retuse; 5, Apiculate

61 Flower, sepal, consistency: 0, Membranaceous; 1, Carthaceous; 2, Coriaceous

62 Flower, sepal, carena: 0, Present; 1, Absent

63 Flower, sepal, margin: 0, Entire; 1, Aculeate; 2, Crenate

64 Flower, sepal, concrescence: 0, Free; 1, Conate

65 Flower, petal, position of apex during anthesis: 0, Cuculate; 1, Erect; 2, Recurvate

66 Flower, petal, consistency: 0, Membranaceous; 1, Carnose

Flower, petal, color of blade: 0, White; 1, Pink; 2, Red; 3, Lilac; 4, Purple; 5, Wine-colored; 6, Green; 7, Blue; 8, Black; 9, Yellow

68 Flower, petal, color of margin: 0, The same as the blade; 1, Different from the blade

69 Flower, petal, indumentum: 0, Present; 1, Absent

70 Flower, petal, apex: 0, Acute; 1, Attenuate; 2, Obtuse; 3, Rounded

Flower, petal, form: 0, Oblanceolate; 1, Oblong; 2, Obovate; 3, Elliptical; 4, Linear; 5, Triangular

Flower, petal, concrescence: 0, Free; 1, Conate

Flower, petal, kind of concrescence: $0, \mathrm{Up}$ to $1 / 3 ; 1$, More than $1 / 3$

Flower, petal, appendix: 0, Present; 1, Absent

Flower, petal, callosity: 0, Present; 1, Absent

Flower, stamens, length related to the petals: 0, Exceeding; 1, Not exceeding

Flower, stamens, position related to the petals: 0, Exserted; 1, Included

Flower, stamens, color of anthers: 0, White; 1, Yellow

Flower, stamens, concrescence in relation to petals: 0, Adnate; 1, Free

Flower, stamens, anthers insertion: 0, Basifixed; 1, Dorsifixed

Flower, stamens, anthers form: 0, Oblong; 1, Sagittate; 2, Elliptical

Flower, ovary, position: 0, Superior; 1, Inferior

Flower, ovary, form: 0, Ovate; 1, Elliptical; 2, Oblong; 3, Obovate

Flower, hypanthium, indumentum: 0, Present; 1, Absent

Flower, hypanthium, type of indumentum: 0, Villous; 1, Tomentose; 2, Floccose

Flower, hypanthium, sulcus: 0, Present; 1, Absent

Fruit, type: 0, Berry; 1, Capsule

Fruit, concrescence of external walls: 0, Free; 1, Concrescent

Fruit, petals: 0, Persistent; 1, Not persistent

Seeds, appendix: 0, Present; 1, Absent

Leaf anatomy, abaxial surface, contour: 0 , Smooth to slightly wavy; 1 , Grooved 
Leaf anatomy, epidermal cells of adaxial surface, thickening type: 0 , Strongly thickened inner periclinal wall, 93 reduced lumen; 1, Inner periclinal wall thickened, with a smooth, wide lumen; 2, Strongly thickened outer periclinal wall, reduced lumen

Leaf anatomy, epidermal cells of abaxial surface, thickening type: 0 , Strongly thickened inner periclinal wall, 94 reduced lumen; 1, Inner periclinal wall thickened, with a smooth, wide lumen; 2, Strongly thickened outer periclinal wall, reduced lumen

95 Leaf anatomy, trichome, number of pedicle cells: 0 , Two; 1 , More than two

96 Leaf anatomy, trichome on adaxial surface: 0 , Present; 1 , Absent

97 Leaf anatomy, stomatal apparatus, position related to epidermis: 0, Same level; 1, Down, 2, Up

98 Leaf anatomy, mechanical hypodermis adaxial, thickening: 0 , Present; 1 , Absent

99 Leaf anatomy, mechanical hypodermis adaxial, number of layers: 0, One; 1, Two; 2, Three; 3, Four; 4, Five

100 Leaf anatomy, mechanical hypodermis adaxial, thickening of cell: 0 , Slightly thickened; 1 , Strongly thickened

101 Leaf anatomy, mechanical hypodermis abaxial, number of layers: 0, One; 1, Two; 2, Three; 3, Four; 4, Five

102 Leaf anatomy, mechanical hypodermis abaxial, thickening of cell: 0 , Slightly thickened; 1 , Strongly thickened Leaf anatomy, water-storage hypodermis adaxial, size: 0 , Up to $1 / 3$ of the blade thickness; 1 , More than $1 / 3$ of the blade thickness

104 Leaf anatomy, transition between adaxial water-storage hypodermis and chlorenchyma: 0 , Abrupt; 1 Tenuous

105 Leaf anatomy, adaxial water-storage hypodermis cell shape: 0 , Rounded, 1, Elongated in anticlinal direction

106 Leaf anatomy, water-storage hypodermis, position: 0, Adaxial face; 1, Abaxial face; 2, Both sides

107 Leaf anatomy, brachiform parenchyma, cell shape: 0 , With short arms (forming small gaps); 1, With long arms (forming large gaps)

108 Leaf anatomy, cell of bundle sheath parenchyma, disposition: 0 , Radiate; 1 , Not radiate

109

Leaf anatomy, vascular bundles of smaller diameter, shape of the thickening (fiber): 0 , Taller than wide; 1 , Wider than tall

110 Leaf anatomy, vascular bundles of larger caliber, thickening of fibers: 0, Calotte; 1, Circling totally

111 Leaf anatomy, palisade chlorenchyma, shape: 0 , Palisade; 1, Not palisade; 2, Palisade and not palisade

112 Leaf anatomy, adaxial epidermis, outer periclinal walls: 0 , Smooth; 1, Papillose

113 Leaf anatomy, raphides: 0 , Present; 1 , Absent

114 Leaf anatomy, secretory ducts: 0 , Present; 1 , Absent

115 Leaf anatomy, extravascular fibers: 0 , Present; 1 , Absent

116 Habit: 0, Terrestrial; 1, Rupiculous; 2, Epiphytic

seems to be homoplastic, since it appeared twice independently, in clades $\mathrm{C}$ and $\mathrm{D}$. The species with pedunculate inflorescences appeared at the base of Bromelia, indicating that this character is ancestral in the genus. Interestingly, Ochagavia, Fascicularia and Greigia possess a sunk inflorescence.

In clade $\mathrm{E}$, species possess a large and lax inflorescence, with the peduncle emerging from the rosette; nevertheless, from clade $\mathrm{D}$, as we proceed in the direction of the branches that diverged more recently, the axes of the inflorescence become reduced, and the flowers are arranged closer together (B. balansae, B. reversacantha, B. interior, B. serra and $B$. horstii). Further up clade $\mathrm{D}$, the peduncle of the inflorescence is gradually reduced, such as in B. serra, B. goyazensis and B. horstii, until the inflorescence is completely included within the foliar rosette in B. lindevaldae, B. minima, B. macedoi, $B$. karatas, B. grandiflora, B. villosa and B. lagopus.
The reduction in the size of the inflorescence in Bromelioideae may be an important factor to allow them to occupy xeric environments, optimizing the use of resources in stressful, nutrientpoor environments (Reekie \& Bazzaz 2005). Species of the genus Bromelia are predominantly terrestrial in habit, and their leaves do not absorb water and nutrients efficiently (Benzing 2000); therefore, they depend on the soil for water and nutrient balance. The environments of the Cerrado (Ratter et al. 1997) and restinga (Mantovani \& Iglesias 2001, 2008) are notorious for their oligotrophic and rapidly draining soils. The little information available about the cost of producing inflorescences in bromeliads indicates that more biomass is allocated to pedunculate inflorescences (Benzing 2000; Mantovani \& Iglesias 2009). At the same time, studies of the nested inflorescence have shown that the input of carbon in this type of 
inflorescence is potentially much smaller than that in a peduncular inflorescence (Benzing \& Ott 1981).

Finally, Bromelia minima, B. macedoi and

$B$. lindevaldae, the clade F, small-sized species that occur almost sympatrically in the cerrado, emerge as a single group, even when metric data are not included in the analysis. In these species the nutrient-allocation economy is not associated only with sexual reproduction (i.e., the absence of a peduncle), because this would be insufficient for a positive nutrient balance under the conditions in the Cerrado. Therefore, the reduction has extended to the plant body, whose smaller size can improve the heat balance through convection (by reducing the surface/ volume ratio of the leaves) and microclimate protection (a smaller hydric deficit next to the soil), in addition to requiring less carbon and nutrients for its construction (Vieira \& Mantovani 1995).

\section{Conclusion}

The evolution and diversification of the Bromelioideae remain to be extensively explored, seeing that the basis for their understanding lies in the clades that branched first in this subfamily, which until now have been little studied. For this purpose, it is necessary to carry out a thorough study of these genera (which are also inadequately collected), since they possess a larger number of symplesiomorphies and is one of the closest genera to the most recent common ancestor of the Bromelioideae. The present analysis of Bromelia and Fernseea is a first step toward this end. It would be desirable to continue proposing new phylogenetic hypotheses for these groups, with the most varied types of characters available, including molecular characters (DNA sequences, AFLPs and microsatellites). This process may lead additional evolutionary inferences, with stronger support.

The present study provides also the necessary foundation to futher elucidate character evolution in Bromelia, since some morphological characters may carry strong phylogenetic signals in bromeliads (Louzada et al. 2014), and morphological studies of these characters are desirable.

Analyses at the infrageneric level, involving several terminals of the same genus, can change the fine structure of the evolutionary history (Wagner et al. 2012), indicating that occupation events (multiple events, versus a single entry), routes, or modes of diversification (e.g., sympatry versus allopatry) should be re-evaluated, and should continue.

\section{Acknowledgements}

RFM gratefully acknowledges CAPES and $\mathrm{CNPq}$ for the award of a grant for postgraduate studies. The authors thank the curators of the herbaria mentioned in the text, for the loan of material; Bruno Resende, Nara Vasconcelos and Elton M. C. Leme for providing live material; Vitor Hugo Maia for help with the analysis; Beatriz Castellar Duque-Estrada, Rodrigo das Neves Costa and Fernanda dos Santos Silva for help with the figures; and Renato de Mello-Silva, Cássia Mônica Sakuragui, Andrea Costa and the anonymous reviewers for their valuable suggestions on the manuscript. RCF is a CNPq research fellow.

\section{References}

Almeida, V.R.; Costa, A.F.; Mantovani, A.; GonçalvesEsteves, V.; Arruda, R.C.O. \& Forzza, R.C. 2009. Morphological Phylogenetics of Quesnelia (Bromeliaceae, Bromelioideae). Systematic Botany 34: 660-672.

Amorim, A.M.A.; Thomas, W.W.; Carvalho, A.M.V. \& Jardim, J.G. 2008. Floristics of the Una Biological Reserve, Bahia, Brazil. Memoirs of the New York Botanical Garden 100: 67-146.

Antonelli, A.; Nylander, J.A.A.; Persson, C. \& Sanmartín, I. 2009. Tracing the impact of the Andean uplift on Neotropical plant evolution. PNAS Proceedings of the National Academy of Sciences 106: 9749-9754.

Antonelli, A. \& Sanmartín, I. 2011. Why are there so many plant species in the Neotropics? Taxon 60: 403-414.

Assis, L.C. 2009. Coherence, correspondence, and the renaissance of morphology in phylogenetic systematics. Cladistics 25: 528-544

Baker, G. 1889. Handbook of the Bromeliaceae. George Bell and Sons, London. 243 p.

Benzing, D. 2000. Bromeliaceae: profile of an adaptive radiation. Cambridge University Press, UK. 690 p.

Benzing, D.H. \& Ott D.W. 1981. Vegetative reduction in epiphytic Bromeliaceae and Orchidaceae: its origin and significance. Biotropica 13: 131-140.

Bremer, K. 1994. Brach support and tree stability. Cladistics 10: 295-304.

Carswell, F.E.; Meir, P.; Wandelli, E.V.; Bonates, L.C.; Kruijt, B.; Barbosa, E.M.; Nobre, A.D.; Grace, J. \& Jarvis, P.G. 2000. Photosynthetic capacity in a central Amazonian rain forest. Tree Physiology 20:179-186.

Cavalcanti, D. \& Tabarelli, M. 2004. Distribuição das plantas amazônico-nordestinas no centro de endemismo Pernambuco: brejos de altitude vs. florestas de terras baixas, In: Porto, K.C.; Cabral, J.J.P. \& Tabarelli, M. (eds.). Brejos de altitude em 
Pernambuco e Paraíba: História Natural, Ecologia e Conservação. Porto Série Biodiversidade 9. Brasília DF, Ministério do Meio Ambiente - MMA. 285-296.

Clark, W. \& Clegg, M.T. 1990. Phylogenetic comparisons among $r b c L$ sequences in the Bromeliaceae. American Journal of Botany 77: 115.

Calazans, L.S.B.; Sakuragui, C.M. \& Mayo, S.J. 2014. From open areas? The evolutionary history of Philodendron subgenus Meconostigma (Araceae) using morphological data. Flora 209: 117-121.

Crayn, D.M.; Winter, K. \& Smith, J.A.C. 2004. Multiple origins of crassulacean acid metabolism and the epiphytic habit in the Neotropical family Bromeliaceae. PNAS Proceedings of the National Academy of Sciences 10: 3703-3708.

Donadío, S.; Pozner, R. \& Giussani, L.M. 2014. Phylogenetic relationships within Tillandsia subgenus Diaphoranthema (Bromeliaceae, Tillandsioideae) based on a comprehensive morphological dataset. Plant Systematics and Evolution 301: 387-140.

Evans, T.M.; Jabalily, R.S.; Faria, A.P.G.; Sousa, L.O.F.; Wendt, T. \& Brown, G.K. 2015. Phylogenetic relationships in Bromelioideae based on chloroplast DNA sequence data. Systematic Botany 40: 116-128.

Faria, A.P.G.; Wendt, T. \& Brown, G.K. 2004. Cladistic relationships of Aechmea (Bromeliaceae, Bromelioideae) and allied genera. Annals of the Missouri Botanical Garden 91: 303-319.

Felsenstein, J. 1985. Confidence limits on phylogenies: An approach using the bootstrap. Evolution 39: 783-791.

Forzza, R.C. 2001. Filogenia da tribo Puyeae Wittm. e revisão taxonômica do gênero Encholirium Mart. ex Schult. \& Schult.f. (Pitcairnioideae, Bromeliaceae). Tese de Doutorado. Universidade de São Paulo, São Paulo. 208p.

Forzza, R.C.; Costa, A.; Siqueira Filho, J.A.; Martinelli, G.; Monteiro, R.F.; Santos-Silva, F.; Saraiva, D.P.; Paixão-Souza, B.; Louzada, R.B. \& Versieux, L. 2014. Bromeliaceae. In: Lista de Espécies da Flora do Brasil. Jardim Botânico do Rio de Janeiro. Available at $<$ http://floradobrasil.jbrj.gov.br/jabot/ floradobrasil/FB66>. Access on 13 October 2014.

Givnish, T.J.; Barfuss, M.H.J.; Van Ee, B.; Riina, R.; Schulte, K.; Horres, R.; Gonsiska, P.A.; Jabaily, R.S.; Crayn, D.M.; Smith, J.A.C.; Winter, K.; Brown, G.K., Evans, T.M.; Holst, B.K.; Luther, H.; Till, W.; Zizka, G.; Berry, P.E. \& Sytsma K.J. 2014. Adaptive radiation, correlated and contingent evolution, and net species diversification in Bromeliaceae. Molecular Phylogenetics and Evolution 71: 55-78.

Givnish, T.J.; Barfuss, M.H.J.; Van Ee, B.; Riina, R.; Schulte, K.; Horres, R.; Gonsiska, P.A.; Jabaily, R.S.; Crayn, D.M.; Smith, J.A.C.; Winter, K.; Brown, G.K.; Evans, T.M.; Holst, B.K.; Luther, H.; Till, W.; Zizka, G.; Berry, P.E. \& Sytsma K.J. 2011. Phylogeny, adaptive radiation, and historical biogeography in Bromeliaceae: Insights from an eight-locus plastid phylogeny. American Journal of Botany 98: 872-895.

Givnish, T.J.; Millam, K.C.; Berry, P.E.; Sytsma, K.J. 2007. Phylogeny, adaptive radiation, and historical biogeography of Bromeliaceae inferred from $n d h F$ sequence data. In: Columbus, J.T.; Friar, E.A.; Porter, J.M.; Prince, L.M. \& Simpson, M.G. (eds.) Monocots: Comparative Biology and Evolution - Poales, Rancho Santa Ana Botanic Garden, Claremont. Pp. 3-26.

Givnish, T.J.; Millam, K.C.; Evans, T.M.; Hall, J.C.; Pires, J.C.; Berry, P.E. \& Sytsma, K.J. 2004. Ancient vicariance or recent long-distance dispersal? Inferences about phylogeny and South American-African disjunctions in Rapateaceae and Bromeliaceae. International Journal of Plant Sciences 165: 35-54.

Gomes-da-Silva, J.; Vargens, F.A.C.; Arruda, R.C.O. \& Costa, A.F. 2012. A morphological cladistic analysis of the Vriesea corcovadensis group (Bromeliaceae: Tillandsioideae), with anatomical descriptions: new evidence of the non-monophyly of the genus. Systematic Botany 37: 641-654.

Haffer, J. 1969. Speciation in Amazonian forest birds. Science 165: 131-137.

Haffer, J. \& Prance, G.T. 2002. Impulsos climáticos da evolução na Amazônia durante o Cenozóico: sobre a teoria dos Refúgios da diferenciação biótica. Estudos Avançados 16: 175-206.

Hornung-Leoni, C. \& Sosa, V. 2008. Morphological phylogenetics of Puya subgenus Puya (Bromeliaceae). Botanical Journal of the Linnean Society 156: 93-110.

Horres, R.; Schulte, K.; Weising, K. \& Zizka, G. 2007. Systematics of Bromelioideae (Bromeliaceae) Evidence from molecular and anatomical studies. Aliso 23: 27-43.

Horres, R.; Zizka, G.; Kahl, G. \& Weising, K. 2000. Molecular phylogenetics of Bromeliaceae: evidence from trnL (UAA) intron sequences of the chloroplast genome. Plant Biology 2: 306-315.

Jabaily, R.S. \& Sytsma, K. J. 2010. Phylogenetics of Puya (Bromeliaceae): placement, major lineages, and evolution of Chilean species. American Journal of Botany 97: 337-356.

Leme, E.M.C. \& Siqueira Filho, J.A. 2006. Fragmentos de Mata Atlântica do Nordeste. Biodiversidade, Conservação e suas Bromélias. Andrea Jakobson Estúdio, Rio de Janeiro. 416p.

Louzada, R.B. 2012. Revisão taxonômica e filogenia de Orthophytum Beer (Bromeliaceae, Bromelioideae). Tese de Doutorado. Universidade de São Paulo, São Paulo. 186p.

Louzada, R.B.; Schulte, K.; Silvestro, D.; Zizka, G.; Wanderley, M.G.L.; Barfuss, M.H.J. \& Palma-Silva, C. 2014. Molecular phylogeny of the Brazilian endemic genus Orthophytum (Bromelioideae, Bromeliaceae) and its implications 
on morphological character evolution. Molecular Phylogenetics and Evolution 77: 54-64.

Maddison, W.P. \& Maddison, D.R. 2011. Mesquite: a modular system for evolutionary analysis. Version 2.75. Available at <http://mesquiteproject.org $>$. Access on 13 October 2013.

Mantovani, A. \& Iglesias, R.R. 2001. Bromélias terrestres na restinga de Barra de Maricá, RJ: influência sobre o microclima, o solo, e a estocagem de nutrientes em ambientes de borda de moitas. Leandra 16: 17-37.

Mantovani, A. \& Iglesias, R.R. 2005. Quando aparece a primeira escama? Estudo comparativo sobre o surgimento de escamas de absorção em três espécies de bromélias terrestres de restinga. Rodriguésia 56: 73-84.

Mantovani, A. \& Iglesias, R.R. 2008. Factors limiting seed germination of terrestrial bromeliads in the sandy coastal plains (restinga) of Maricá, Rio de Janeiro, Brazil. Rodriguésia 59: 135-150.

Mantovani, A. \& Iglesias, R.R. 2009. Size-dependent allocation of biomass to ancillary versus flowers of the inflorescences of the epiphyte Tillandsia stricta Soland (Bromeliaceae). Acta Botanica Brasilica 23: 130-135.

Mantovani, A.; Venda, A.K.L.; Almeida, V.R.; Costa, A.F. \& Forzza, R.C. 2012. Leaf anatomy of Quesnelia (Bromeliaceae): implications for the systematics of core bromelioids. Plant Systematics and Evolution 298: 787-800.

Mantuano, D.G. 2008. Crescimento clonal de Neoregelia cruenta na restinga de Jurubatiba: estrutura populacional, plasticidade morfo-anatômica, integração fisiológica. Tese de Doutorado. Instituto de Pesquisas Jardim Botânico do Rio de Janeiro, Rio de Janeiro. 104p

Martinelli, G.; Vieira, C.M.; Gonzalez, M.; Leitman, P.; Piratininga, A.; Costa, A.F. \& Forzza, R.C. 2008. Bromeliaceae da Mata Atlântica brasileira: lista de espécies, distribuição e conservação. Rodriguésia 59: 209-258.

Mez, C. 1891. Bromeliaceae. In: von Martius, C.F.P; Eichler, A.W. \& Urban, I. Flora Brasiliensis. Munchen, Wien, Leipzig. Vol 3, part. 3, pp. 173-634.

Monteiro, R.F.; Forzza, R.C. \& Mantovani, A. 2011. Leaf structure of Bromelia and its significance for the evolution of Bromelioideae (Bromeliaceae). Plant Systematics and Evolution 293: 53-64.

Nixon, K.C. 2002. WinClada ver. 1.00.08. Published by the author, Ithaca, New York. Available at $<$ http:// www.cladistics.com>. Access on 10 February 2015.

Nixon, K.C. \& Carpenter, J.M. 1993. On outgroups. Cladistics 1: 413-426.

Novaes, R.M.L; Filho, J.P.L.; Ribeiro, R.A. \& Lovato, M.B. 2010. Phylogeography of Plathymenia reticulata (Leguminosae) reveals patterns of recent range expansion towards northeastern Brazil and southern Cerrados in Eastern Tropical South America. Molecular Ecology 19: 985-998.
Pennington, R.; Lavin, M.; Prado, D.; Pendry, C.; Pell, S. \& Butterworth, C. 2004. Historical climate change and speciation: neotropical seasonally dry forest plants show patterns of both Tertiary and Quaternary diversification. Philosophical Transactions of the Royal Society 359: 515-538.

Pereira, E. \& Moutinho, J.L.A. 1983. "Species Novae in Brasilia Bromeliacearum - XX” Bradea 3: 339-348.

Pereira, O.J. \& Araújo, D.S.D. 2000. Análise florística das restingas dos estados do Espírito Santo e Rio de Janeiro. In: Esteves F.A. \& Lacerda L.D. Ecologia de Restingas e Lagoas Costeiras. NUPEM/UFRJ, Rio de Janeiro. Pp. 25-63.

Prado, D.E. \& Gibbs, P.E. 1993. Patterns of species distributions in the dry seasonal forests of South America. Annals of the Missouri Botanical Garden 80: 902-927.

Prance, G.T. 1987. Biogeography of Neotropical plants. In: Whitmore, T.C. \& Prance, G.T. Biogeography and Quaternary history in tropical America. Oxford Monographs on Biogeography. Clarendon Press, Oxford. Pp. 46-65.

Radford, A.E; Dickison, W.C; Massey, J.R. \& Bell, C.R. 1974. Vascular plant systematics. Harper and Row, New York. 891p.

Ramírez-Morillo, I.M.; Fernández-Concha, G.C. \& ChiMay, F. 2004. Guía Ilustrado de las Bromeliceae de la porción mexicana de la Península de Yucatán. Centro de Investigación Científica de Yucatán, A.C. Mérida, Yucatán. 124p.

Ratter, J.A.; Ribeiro, J.F. \& Bridgewater, S. 1997. The Brazilian cerrado vegetation and threats to its biodiversity. Annals of Botany 80: 223-230.

Reekie, E.G. \& Bazzaz, F.A. 2005. Reproductive Allocation in Plants. Physiological Ecology. Series. Elsevier Academic Press, London. 247p.

Rex, M.; Patzolt, K.; Schulte, K.; Zizka, G.; Vásquez, R.; Ibisch, P.L. \& Weising, K. 2007. AFLP analysis of genetic relationships in the genus Fosterella L.B. Smith (Pitcarnioideae, Bromeliaceae). Genome 50: 90-105.

Saraiva, D.P. 2013. Filogenia morfológica de Pitcairnia L'Hér. (Bromeliaceae-Pitcairnioideae). Dissertação de Mestrado. Instituto de Pesquisas Jardim Botânico de Rio de Janeiro, Rio de Janeiro. 79p.

Sajo, M.G.; Machado, S.R. \& Carmello-Guerreiro, S.M. 1998. Aspectos estruturais de folhas de bromélias e suas implicações no agrupamento de espécies. In: Leme, E.M.C. 1998. Canistropsis. Bromélias da Mata Atlântica. Ed. Salamandra, Rio de Janeiro. Pp. 102-111.

Sass, C. \& Specht, C.D. 2010. Phylogenetic estimation of the core Bromelioids with an emphasis on the genus Aechmea (Bromeliaceae). Molecular Phylogenetics and Evolution 55: 559-571.

Schulte, K.; Barfuss, M.H.J. \& Zizka, G. 2009. Phylogeny of Bromelioideae (Bromeliaceae) inferred from 
nuclear and plastid DNA loci reveals the evolution of the tank habit within the subfamily. Molecular Phylogenetics and Evolution 51: 327-339.

Schulte, K.; Horres, R. \& Zizka, G., 2005. Molecular phylogeny of Bromelioideae and its implications on biogeography and the evolution of CAM in the family (Poales, Bromeliaceae). Senckenbergiana Biologica 85: 113-125.

Schulte, K. \& Zizka, G. 2008. Multi locus plastid phylogeny of Bromelioideae (Bromeliaceae) and the taxonomic utility of petal appendages and pollen characters. Candollea 63: 209-225.

Sereno, P.C. 2007. Logical basis for morphological characters in phylogenetics. Cladistics 23: 565-587.

Silvestro, D.; Zizka, G. \& Schulte, K. 2014. Disentangling the effects of key innovations on the diversification of Bromelioideae (Bromeliaceae). Evolution 68: 163-175.

Simon, M.F.; Grether, R.; de Queiroz, L.P.; Skema, C.; Pennington, R.T. \& Hughes, C.E. 2009. Recent assembly of the Cerrado, a neotropical plant diversity hotspot, by in situ evolution of adaptations to fire. Proceedings of the National Academy of Sciences PNAS 106: 20359-20364.

Simonelli, M.; Souza, A.L.; Peixoto, A.L. \& Silva, A.F. 2008. Floristic composition and structure of the tree component of a muçununga forest in the Linhares Forest Reserve, Espírito Santo, Brazil. Memoirs of the New York Botanical Garden 100: 351-370.

Smith, L.B. 1967. Notes on Bromeliaceae. Phytologia 15: 163-200.

Smith, L.B. \& Downs, R.J. 1979. Bromelioideae (Bromeliaceae). In: Flora Neotropica. Hafner Press, New York. Vol 14, part 3, pp 1493-2141.

Swofford, D.L. 2002. PAUP* Phylogenetic analysis using parsimony (*and other methods). Version 4.0. Sunderland: Sinauer Associates, Massachusetts.

Swofford, D.L. \& Maddison, W.P. 1992. Parsimony, character-state reconstructions, and evolutionary inferences. In: Mayden, R.L., (ed.). Systematics, Historical Ecology, and North American Freshwater Fishes. Stanford University Press, Stanford, California. Pp. 187-223.

The Plant List. 2013. Version 1.1. Available at $<\mathrm{http}$ :/ www.theplantlist.org/>. Access on 14 October 2014.

Tomlinson, P.B. 1969. Commelinales-Zingiberales. In: Metcalfe, C.R. (ed.). Anatomy of the Monocotyledons. Claredon Press, Oxford. Pp. 193-294.

Vasconcelos, M.F. 2011. O que são campos rupestres e campos de altitude nos topos de montanha do Leste do Brasil? Revista Brasileira de Botânica 34: 241-246

Versieux, L.M. 2009. Sistemática, filogenia e morfologia de Alcantarea (Bromeliaceae). Tese de Doutorado, Universidade de São Paulo, São Paulo. 252p.

Versieux, L.M.; Barbará, T.; Wanderley, M.G.L.; Calvente, A.; Fay, M.F. \& Lexer, C. 2012. Molecular phylogenetics of the Brazilian giant bromeliads (Alcantarea, Bromeliaceae): implications for morphological evolution and biogeography. Molecular Phylogenetics and Evolution 64: 177-189.

Vieira, R.C. \& Mantovani, A. 1995. Anatomia foliar de Deschampsia antarctica Desv. Revista Brasileira de Botânica 18: 207-220.

Wagner, C.E.; Harmon, L.J. \& Seehausen, O. 2012. Ecological opportunity and sexual selection together predict adaptive radiation. Nature 487: 366-369.

Weberling, F. 1989. Morphology of flowers and inflorescences. Cambridge University Press, Cambridge. $405 \mathrm{p}$.

Zizka, G.; Horres, R.; Nelson, E.C. \& Weising, K. 1999. Revision of the genus Fascicularia Mez (Bromeliaceae). Botanical Journal of the Linnean Society 129: 315-332.

Zizka, G.; Schmidt, M.; Schulte, K.; Novoa, P.; Pinto, R. \& König, K. 2009. Chilean Bromeliaceae: diversity, distribution and evaluation of conservation status. Biodiversity and Conservation 18: 2449-2471. 